\title{
Rethinking the Eucharist in the aftermath of COVID-19 disruptions: A comparative study of Reformed and Pentecostal theology of sacraments
}

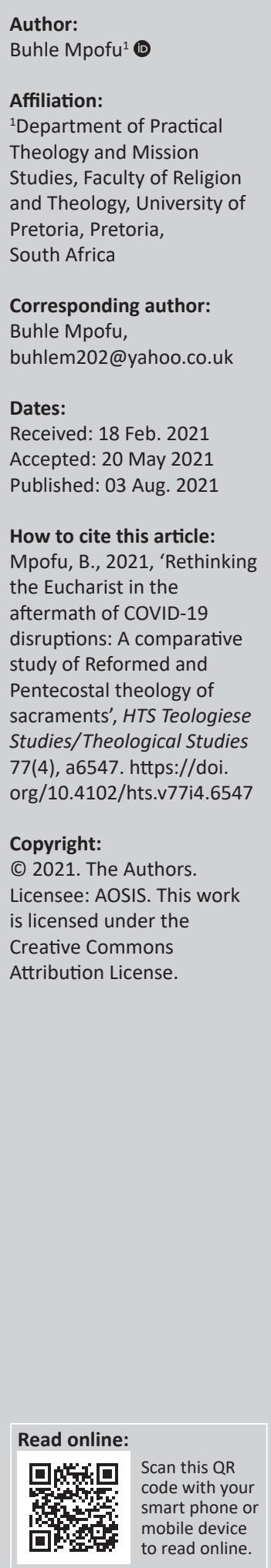

This contribution recommends a re-thinking of Christian traditions with regards to sacraments and use of technology in the context of the coronavirus disease 2019 (COVID-19) pandemic. It is a comparative study that employed field observations from two congregations with different traditions: one from Protestant Reformed tradition and another from Pentecostal Charismatic background to analyse how they conducted Holy Communion services. By highlighting positive aspects of COVID-19 disruptions on traditional practices, the study challenged traditional understanding of 'sacred space' and re-appropriates the virtual role of a priest as symbolic embodiment of the presence of Christ extended through virtual, audio and televisual presence. The contribution also demonstrated how ontological questions help us discern what separates the sacred from the secular and concluded that the transformative nature of the sacrament of the Holy Communion has a uniquely power-levelling role in communities.

Contribution: This article contributes to conversations on the role of technology in sacraments within the Reformed Christian tradition and presents a systematic and practical reflection on the intersecting modes of sacramental practices within different Christian traditions.

Keywords: Eucharist; COVID-19; virtual communities; Reformed theology; Pentecostal theology; transformation.

\section{Introduction}

In a publication 'Artificial Intelligence for Africa: An Opportunity for Growth, Development, and Democratisation', Pillay (2019:2) highlighted the implications of artificial intelligence (AI) in Africa citing various economic and key sectors such as agriculture and education (to name a few) that could improve development by engaging some relevant components of AI technologies to potentially address some contemporary challenges that impact on African economies and enhance economic growth and development in key sectors. Theologically, we are yet to explore the many questions that relate to God's mission and AI. Some of these questions could focus on the ways in which AI can be harnessed to assist in effective mission and humanitarian relief in times of distress and provision of support to isolated individuals or people with disabilities. Therefore, this paper highlights some of the ways in which technology could impact on reformed understanding of mission-religious practices with regard to presence, space and geographical or physical barriers in the effective implementation of 'the mission of God's people' (Wright 2010). Where there are resources, it is time that some activities of the Church migrate to online digital platforms. As Mpofu (2020b) has rightly observed:

[T] he church should emerge from COVID-19 well equipped for a new age of mission. COVID-19 disruptions present an opportunity for emergence of alternative ways of being church and new modes of socioeconomic organization. (p. 6)

Technology played a major role in providing alternative virtual spaces during the coronavirus disease 2019 (COVID-19) disruptions since lockdowns which were imposed in many countries in 2020. Whilst there is hope with nations now scrambling for the vaccine in order to limit restrictions and stimulate economic growth, there is a need to closely examine how technology can continue to be useful in enhancing life and mission of the church. It has been encouraged that the

Note: Special Collection: Theology, Economy and Environment: Cultural and Biotic Influences on Religious Communities, sub-edited by Jerry Pillay (University of Pretoria). 
church should come out of COVID-19 disruptions properly 'equipped for a new age of mission' (Mpofu 2020:6). This is critical given that most communities that have access to internet and electronic gadgets, the majority of whom are young people, have been at the forefront of technological advancement as they rely on technology to communicate and access games through a variety of technological applications and platforms during the COVID-19 lockdown. In a recent publication highlighting the creativity of young people, Mpofu (2020a) reflected on how migrant adolescents navigate the changing cultural landscapes in their quest for identity and belonging in host communities where they are often marginalised (Mpofu 2020b). Such creativity can be harnessed to enhance the mission of the church.

The field visits made by the researcher who worshipped at the nearby Lighthouse City Church (LCC) on some Sundays, made it possible to observe the use of technology in conducting of Holy Communion at the inner-City Pentecostal congregation in Pietermaritzburg, South Africa in 2017 where the Eucharist was celebrated through a televised blessing offered by the Bishop of an international ministry. ${ }^{1}$ These observations inspired the comparison of those practices with what has been observed and experienced within the Reformed Protestant congregations where Communion is taken only in the presence of the ordained minister. It was fascinating to see how technology was changing the missional landscape even before COVID-19 impacted on the programs of the churches as the creative use of digital space for the Eucharist reflected complex dynamics of socio-spatial interconnectedness. What does it mean to attend a communion service online versus physically attending in the presence of a dispensing minister? The COVID-19 disruptions presented an opportunity to interrogate traditional practices related to dispensing of the Holy Communion within the Reformed tradition and explore other missional alternatives. Mpofu (2021) also observed that the creative use digital connections and spaces demonstrate how transnational faith communities create digital liturgical spaces across borders that redefined 'presence' and the 'none present' in ways that could enhance mission in the era of social distancing necessitated by responses to COVID-19:

The pragmatic implications of these emerging forms of belonging and presence as non-presence generate the 'antipresence' and disrupt the traditional notion of membership because it is not necessary for the faithful to be physically there; all other users can be digitally present, along with the rest of the members who may be listed in a membership role. In that sense, digital users create a sacred space accessible to any online users, and this opens religious imaginaries to creative engagement and possible interpretations or reconstructions, which present opportunities for an endless missional hermeneutic with new meanings. (p. 5)

The emerging forms of belonging in the context of COVID-19 require that we only gather or visit when it is extremely necessary, otherwise technology allows us to stay in touch

1.More details and an example of Bishop Dag Heyward's online ministry are available at: https://www.youtube.com/watch?v=dx3DmW5dEvk\&list=RDCMUCmpJUHS40N at: https://www.youtube.com/watch?v=dx3DmW5dEvk\&list=RDCM
NiHGCV_K7ya-A\&start_radio=1\&t=6442 [Accessed 17 May 2021]. without risking being infected by corona virus disease COVID-19. By analysing and comparing the liturgical practices of the two congregations, this article aims to recommend the use of technology in re-thinking of the traditional approaches to Christian mission in the face of COVID-19 pandemic and to highlight how the dispensing of the Eucharist through a televised presence of the minister 'present in the non-presence', disrupts the protestant understanding of the sacraments and highlights the need to re-think traditional Christian practices in the light of emerging virtual faith communities accelerated by the COVID-19 lockdowns. These developments reflect that there is a need to explore emerging forms of mission within the context of $\mathrm{AI}$ and new communication technologies.

There are some scholars who have explored the role of technology in Christian practice within the African context. For example, Okyere Manu (2018) reflected on the liturgical practices and rituals in Cyber space after watching an advertisement in which a minister of religion blessed a marriage through Skype because he could not travel to the event that was out of town. She also raised questions on whether or not online liturgical practices constitute an authentic experience noting that technology offers opportunities to do ministry in a new way. Related questions on $\mathrm{AI}$ and the human condition have been raised through topics addressing the intersections between technology and human encounters. According to Schuurman (2019:69), in the book 'Faith and Hope in Technology', the term 'technicism' is a word that has been crafted to describe the intersections of faith and technology. In another book titled, 'Infinite Progress: How the Internet and Technology Will End Ignorance, Disease, Poverty, Hunger, and War', Byron Reese (2013) explored the possibility of replacing humanity's trust in the Creator with technology in ways that are indicative of how technology has fast become idolised. As Schuurman (2019) rightly observed:

\footnotetext{
... This is essentially a form of idolatry, replacing a trust in the creator with technology. In fact, this trust becomes explicit in the case of the 'Way of the Future', a religious group founded by Anthony Levandowski, a former Google and Uber engineer who is working to 'develop and promote the realization of a Godhead based on Artificial Intelligence' and that 'through understanding and worship of the Godhead, [to] contribute to the betterment of society' (Harris 2017:1). The transhumanist Zoltan Istvan suggests that this new AI deity 'will actually exist and hopefully will do things for us'. Solon (2017:1)
}

Examining the role of technology in liturgy, Duce (2013:170) made a "Theological inquiry regarding the practice of the Eucharist in Cyberspace' and observed that people who were affiliated to religious groups were more interested in preserving their Eucharistic practices, whilst others were more open to technological advancement. In another study analysing the use of technology on how it can be innovatively employed in liturgy, Janice came to a conclusion that such creativity involves a level of engagement in which the criteria of a networked community for Eucharist 
exist and argued that any negotiated use of the Internet should consider aesthetic elements that make for a robust engagement in using the medium. Other scholars such as Denny and Wepener (2013) also acknowledged the impact of technology on liturgical practices concurring that Charismatic churches reflect a new phenomenon amongst the churches in Africa whose celebration and liturgy or order of the service of the communion is not the same as that previously observed in the traditional church (Denny \& Wepener 2013).

In concurring with the above observations regarding the necessary liturgical transformation as a response to emerging challenges under new circumstances as we have observed in COVID-19 disruptions, Mbamalu (2015) rightly noted:

$[W]$ henever a dominant theological or liturgical paradigm no longer serves as an effective framework for the interpretation of the concerns of a people's existential contexts, then a paradigm shift in liturgical hermeneutics becomes inevitable. Evidently, when a paradigm becomes irrelevant, its language also becomes obsolete within the changing context and since liturgy and theology are dynamic interactive processes within contexts, a re-visitation of its articulation calls for a constant academic endeavor. (p. 8)

In exploring the different practices of the Eucharist from these two congregations with regard to the use of technology, this article draws on the concept of 'sacred pedagogy' developed by Yves Congar who edited a series of reflections treating the liturgical developments in the Vatican II (Congar 1967:123) and observed that whilst the world is not sacred in itself, there is an important difference between acknowledging the good offered by technological advancement and discerning the 'sacred'. For him, a line needs to be drawn between what Christians consider to be 'Christ's body' - as sacred reality and the 'body of Christ', which is the ecclesial body, his Church - and his 'Eucharistic' body whose mystical presence is celebrated. According to Congar, the world can become 'sacred' in the sense that all of God's creation can be seen as signs of God's presence - not an ontological transformation but perceptual transformation on the part of the believers. In other words, faith and being led the Holy Spirit enable the Church to take up these worldly realities (pedagogically) and present them in such a way as to lead the world to the grace of Christ, a process that Congar calls 'sacred pedagogy' (Arnold 2018:1). For this article, the understanding of functional-ontological distinction between the world (including its own autonomously created technologies) and the 'sacred' body of Christ - offers a lens to analyse how the mission of the Church is a process of 'extending the Incarnation' by way of modern technology. I will now reflect on the liturgical order from both the Reformed and Pentecostal traditions. For purposes of clarity, I have separated these two sections and will begin with the Reformed practice of dispersing Holy Communion.

\section{Holy Communion from the Reformed and Pentecostal perspectives - A comparison}

The Reformed tradition recognises baptism and the Eucharist as two sacraments, and these are reflected in the Heidelberg Catechism (Q65), which defines them as (Christian Reformed Church 2011):

[ $\mathrm{V}$ ]isible, holy signs and seals for us to see. They were instituted by God so that by our use of them he might make us understand more clearly the promise of the gospel, and seal that promise. ${ }^{2}$ (p. 1)

By referring to sacraments as 'signs', the Reformed tradition does not deny the 'real presence' of Christ in the Eucharist but 'redefines the mode and locus of that presence with greater theological and philosophical precision'. Given the practices of televised Eucharistic blessing, the Reformed practice of limiting the dispensing of sacraments only to the 'presence' of ordained or licensed individuals may be challenged in the context of AI where robots could disperse the sacrament. This observation also extends the debate on 'presence' to move beyond the elements of bread and wine and Christ to the minister or dispenser of the sacrament. According to De Gruchy (2013), real presence cannot be confined to the elements of bread and wine:

Christ is truly present in the word proclaimed, in the community of faith that is 'his body', in the bread and wine in the neighbor or 'other' through whom he encounters us. (p. 2)

Therefore, the debate on the 'real presence' of Christ in the sacrament of bread and wine should also include the question of whether the minister should be physically present or that his 'presence' can be replaced through audio-visual equipment. Calvin's used symbols (these can be understood differently) to explain that they communicate the reality to which they refer (De Gruchy 2013):

[S]o the breath that gives us life corresponds with the Spirit who renews us; the water that cleanses our bodies is the water in which we are baptised into Christ; the bread we eat and the wine we drink are the same as those elements that nourish us at the Eucharist. And just as bread we eat and wine we drink change as they enter our bloodstream in order to sustain our lives, the bread and wine of the Eucharist 'are set apart from all common use' and in some significant way become what they signify. (p. 5)

As part of this debate, the Catholic doctrine of 'transubstantiation' of Christ as 'true presence' in the consecrated elements of bread and wine was adopted at the Fourth Lateran Council in 1215 after a debate sparked by Berenger of tours and was later reaffirmed at the Council of Trent in the 16th century (De Gruchy 2013:6). Berenger held the view that it was not necessary to hold that there is the physical change (trans substance) in the elements in order to trust that Christ is present in the Eucharist. John Calvin encouraged believers to take weekly Holy Communion and 2.For more details, see https://www.crcna.org/sites/default/files/HeidelbergCatechism. pdf page 91. 
made this one of the conditions before he agreed to leave Strasbourg and return to Geneva.

Although the early church celebrated communion every week, a number of Protestant congregations now celebrate communion quarterly or monthly for fear that the sacrament will lose its special quality (Huyser-Honig 2007). Historically speaking, people who took part in the Lord's Supper were given communion tokens or cards that were earned through attending preparatory classes. Some Protestant congregations have what they refer to as 'fencing the table' (Watkins 2011) wherein the minister will invite 'only' those who have the right to come to the table and 'debar' the rest 'who have no right to sit on the Table' by giving appropriate descriptions of those who are not the people of God. They state that they have no 'closed communion policy' but insist that taking part in the communion must be limited to those previously admitted by the Session [leadership] (Watkins 2011). Besides allowing Communion only to those approved, in the reformed tradition, the act of dispensing of sacraments is a ministry reserved to ordained or licensed clergy, with a few exceptions where permission has to be sought from the Church councils. This is contrary to mission being understood as the responsibility of all believers, as reflected in the doctrine of 'priesthood of all believers' conducting baptisms, dispensing the Holy Communion and officiating in marriages ${ }^{3}$ are a ministry reserved for the clergy. As a result, there are vacant congregations who rely on 'interim moderators' ${ }^{4}$ for monthly communion visits. Given that some ministers have more than four outstations, this means that ministers allocate at least one Sunday a month for Holy Communion. ${ }^{5}$ In some cases, congregations go for up to 3 months without the Holy Communion because the minister is committed elsewhere.

Within the Pentecostal congregation in Pietermaritzburg, Holy Communion is observed every week during Sunday morning worship although the local minister is sometimes away visiting other congregations. The service starts with worship and intercessory prayers led by one of the elders on duty and worship team. There would be testimonies, musical items and offerings and then a sermon delivered by the local minister or delegated elder - if the minister is not present, the minister's wife conducts services. ${ }^{6}$ After the

3.Although celebrated as a sacrament within the Catholics, marriages are no considered to be part of the sacraments within the Reformed Tradition.

4.An Interim moderator is a minister who provides temporal pastoral duties to a vacant congregation while they undergo through a process to fill the vacancy. This interim period should be within nine months but there a growing trend of minister being these temporal positions for more than two years as a result of congregations being unable to meet the financial obligations that come with appointing a full-time minister.

5.For example, in the Uniting Presbyterian Church in Southern Africa (UPCSA), there are ministers who have over 20 out-stations spread out in the rural areas, an example is Gilepsy UPCSA in Mount Frere in the Eastern Cape.

6.The role of a minister's wife in the Pentecostal churches is different from that of the reformed churches. In the Pentecostal or Charismatic movement, the minister's wife automatically assumes the role of a minister and can dispense sacraments whilst in the reformed tradition the sacraments and pastoral ministry are assigned whilst in the reformed tradition the sacraments and pastoral ministry are assigned
to the minister whilst the minister's wife overseas the ministry of women with the to the minister whilst the minister's wife overseas the ministry of women with the
church. However, we are also seeing a shift in the reformed practices as more sermon, Communion elements of bread and wine would be distributed to members as the worship team leads the congregation through worship after which members stand on their feet and gaze up the screens in anticipation of the Bishop to bless the Communion. When all members have both the elements wine and bread, the program director will announce, 'Let's welcome our Father the Bishop Doug Heward' and members will shout 'Amen!' in anticipation for the televised dispensing of the Holy Communion by the Bishop.

\section{The great entry or invitation to the Lord's 'table'}

Pentecostal congregations are less stringent when it comes to restricting access to the Lord's Table. Firstly, there is no Communion 'table' because Communion elements are directly distributed to individual members just before the screening of a televised blessing. Secondly, participation in the Holy Communion is not based on confirmation of membership; therefore there is no isolation of non-members. Examining Communion practices amongst the Pentecostal Churches in Nigeria, Mbamalu (2015:5) noted that Pentecostals have no defined or uniform order of Communion service and summed up their order of service as follows: An opening prayer, then praise and worship are conducted through an opening hymn, followed by Scripture readings, the Sermon, prayer for sanctification of bread and wine. After this, the blessing is pronounced, then bread and wine served, followed by a personal time for prayer and reflection. The celebration proceeds to conclude with another round of praise and worship, taking of love offering, then Announcements, Closing hymn, Prayer and Benediction.

This practice can be situated within the context of the Lighthouse International Church (LIC) in Pietermaritzburg branch where an invitation to the Communion is extended by the announcement, depending on the Master of Ceremonies for the day. For example, on the day the video being analysed was screened, the invitation was announced through the words:

'Let's us now listen to the Bishop, our father giving us the Holy Communion.' (Program director, LCI, 25 Nov 2018)

\section{Blessing of elements}

The following excerpts and prayers were taken from a video of a Holy Communion service, which was conducted by Bishop Dag Heyward at a Camp meeting in the Memphis, United States of America on 01 May 2016.

When the Bishop Heyward (2016) appears on the screen, he proclaimed:

This is the flesh of Jesus Christ... whatever can not be in the flesh of Jesus, can not be in our flesh. In the name of Jesus, we receive this supernatural meal and supernatural flesh ... the body of Christ ... (n.p.)

ministers now train for full time with their spouses who later assume roles of ordained ministry. 7.These prayers are available through the following reference already listed in the
bibliography: Heyward, D., 2016, 'Watch the consecration ceremony, live from the Anagkazo Campus, Mampong - Ghana', YouTube, viewed 17 May 2021, from https:// Anagkazo Campus, Mampong - Ghana', YouTube, viewed 17 May 2021, from https://
www.youtube.com/watch?v=dx3DmW5dEvk\&list=RDCMUCmpJUHS40NNiHGCV_ K7ya-A\&start_radio $=1 \& \mathrm{t}=6442 \mathrm{~s}$ 
Then the Bishop (2016) holds the cup and says:

'My blood you should drink indeed,

Whatever mistakes you made before coming here ... because of the blood of Jesus ... you are delivered ...' (n.p.)

The concept of declaring deliverance is derived from the book of Psalms 113:7 that present God as a transformative and restorative deity who intervenes both in the past and in all times offering protection to the weak and defenseless members of society. Social outcasts have their dignity and honor restored. No reference is made to 1 Corinthians 11:24-25, which is regarded as the focal scripture for the institution of the Holy Communion as instructed by Paul:

$[A]$ nd when he had given thanks, he broke it and said, 'This is my body, which is for you; do this n remembrance of me'. 25 In the same way, after supper, he took the cup, saying, 'This cup is the new covenant in my blood; do this, as often as you drink it, in remembrance of me'. (vv. 24-25)

Before drinking wine, the Bishop (2016) pronounces:

'As the blood of Jesus enters your body, it neutralizes the poisons of pharaoh and all wicked things in your body' ... and lifts the cup saying 'the blood of Jesus' before he drinks and the congregation follows suit.' (n.p.)

There is no clear reference to Scripture, instead, there is emphasis on the perceived 'power' of the blood of Christ. This lack of clear reference to scripture or systematic hermeneutical approach in Pentecostal liturgy is a weakness that has been identified amongst Pentecostals as a pervasive phenomenon by McCain (2011) who observed:

\footnotetext{
... I currently teach on an adjunct basis at both West Africa Theological Seminary, Lagos [WATS] and Evangel Theological Seminary, Jos [ETS], both of whom enroll primarily Pentecostal students. I have found them to be very eager students and often very good students but as a general rule, I have found them to have less general knowledge about theology and hermeneutics, in particularly, than their counterparts in the mainstream churches. Because of this limitation, there is a tendency within Pentecostal churches to preach textual sermons in which the preacher focuses on just one phrase of Scripture. (p. 16)
}

Given that Pentecostals do not liturgically conduct their services as the Reformed do, the Bishop's approach assumes that the blood of Jesus, spiritually reaches out to the members and cleanses them of any 'wicked things' in their bodies. Given that Pentecostalism is not just different because of its nature of spirituality but also because of the worldview, Pentecostals always assume a spiritual worldview. The worldview is based on an understanding that a spirituality that does not practically transform the lives of people is not worth much. As a result, they seek practical expressions of spirituality and life in ways that demonstrate the vitality in their faith. The awareness that there is an immediately available God, the God of the present moment, not one of a distant past, underscores how Pentecostals do theology and reflects their encounters with God and with the Holy Spirit who is at the centre of all their spiritual expressions.
This understanding is also evident in their prayers as demonstrated below:

\section{Intercessory prayers}

Deliver us from admissions in hospital, we reject cancer and all forms of sickness, in Jesus' name we are delivered ... This marks the end of struggles, whatever is tormenting us, it has lost its power, I curse it and I reject it in the name of Jesus ... Now I pray for all the children let them serve you, let them fear you ... I pray that evil will pass over your children and go to another house and not to our houses. Deliver us from terror Lord ... from outbreaks ... let there be no need for medical care, deliver us ... in Jesus' name ... I pray that evil will pass over your children and go to another house and not in our houses. (Dag Heyward 2016:n.p.)

\section{Order Holy Communion within the protestant congregation}

Within the Reformed tradition, the setting up of the Communion Table involves pre-service preparation of elements, allocation of tasks to elders and setting up of the elements at the table:

The elements are prepared well in advance of the service and covered. They remain in the vestry or on the table at the back of the church, if the traditional Presbyterian practice of the great Entry (proceeding with the elements to the table during the service) is observed; otherwise they remain on the table itself...elders (and other members) serve the elements at the invitation of the minister ... The minister enters the church preceded by the elders in order. (UPCSA 1986:112.05)

The order of worship would usually follow the Order of Service with Communion through which worship, prayers, reading of Scriptures (Traditionally one reading from the Old Testament, one from the letter [or Acts or Revelation] and one from a Gospel) and the offering are collected and blessed before intimations and the sermon precedes the Communion. After the Sermon, the minister moves to the Communion Table and extends a customary invitation to members of any branch of Christ's church to join in the celebration:

... A suitable hymn or Psalm is sung, during which the elements, if not already upon the Table, may be brought into the Church and laid upon the Lord's Table. If already on the Table they are uncovered. (UPCSA 1986:112.05E)

Then the minister institutes communion as follows:

\section{Institution and blessing of elements}

Beloved in the Lord, attend to the words of the institution of this holy supper of our Lord Jesus Christ, as they are delivered to us by Paul his apostle: 'For I received from the Lord what I also passed on to you: the Lord Jesus Christ, on the night he was betrayed, took bread, and when he had given thanks, he broke it and said, this is my body, which is for you; do this in remembrance of me. In the same way, after supper he took the cup and saying, this cup is the new covenant in my blood; do this whenever you 
drink it, in remembrance of me. For whenever you eat this bread and drink this cup, you proclaim the Lord's death until he comes'. (UPCSA 1986:112.05E)

The service proceeds with the great prayer after which the minister blesses the elements and then takes bread and wine before he gives the elders. In giving the bread, he says: 'Take, eat; this is the body of Christ which is for you; do this in remembrance of him'. And in giving the cup, he says; '...this cup is the new covenant in the blood of Christ, which is shed for many for the forgiveness of sins: drink of it, all of you'. Elders then serve the congregation and when everyone has taken elements are replaced on the Table and covered.

\section{Intercessory prayers}

After serving Communion, the elders take their seats and intercessory prayers are conducted before a closing Hymn and benediction. The following is one example of the intercessory prayers offered after the Communion:

\begin{abstract}
Almighty God, we thank you that in your great love you have fed us at your Table with this spiritual food, and brought us into fellowship with your whole Church in heaven and on earth, strengthening us on our pilgrimage to your eternal kingdom. Send us out into the world in the power of your Spirit, to live and work to your praise and glory. This we ask through your Son Jesus Christ our Lord, who lives and reigns with you in the unity of the Holy spirit, one God for ever and ever. Amen. (UPCSA 1986:112.10E)
\end{abstract}

Unlike in the Pentecostal practice where prayers only focus on believers, Reformed intercessory prayers are usually focussed on contextually relevant issues regarding societal well-being, family life, peace, order and even governance with emphasis on shared responsibility in the world. Whilst prayers from Pentecostals spiritually reach out to the members to cleanse them of any 'wicked things' in their bodies, the Reformed prayers after Holy Communion will extend God's kingdom and grace to the world. Building on the idea observed by Yves Congar that posits the world as not sacred in itself, but there is the good offered by technological advancement that helps us to discern the 'sacred' in the world. Whilst a line needs to be drawn between what Christians consider to be the body of Christ - which is the only sacred reality (Congar 1967:66) and the 'body' of Christ that is the ecclesial body, his Church - and his 'Eucharistic' body whose mystical presence is celebrated - there is no justification in isolating the world or unbelievers from the sacred, the Communion or Table of the Lord.

\section{Communion 'at the table' versus communion 'in fellowship'}

Lighthouse Chapel International is the only congregation where I have attended worship and Holy Communion is celebrated every Sunday even in the absence of the local minister. Firstly, an open policy for all Fellowship members to partake in the Holy Communion is in line with John 10:10, which says: 'Jesus Christ has come so that they may all have life...'. So, there is not discrimination on who sits at the table. In this regard, Pentecostal theology tends to be seen through the eyes of people, not theologians; through the community, not traditions and through their faith and worship, not ancient creeds or confessions. It is a dynamic theological expression, seen through the lens of experience. It is a functional theology that exists to operate, to incorporate an experiential dimension. Pentecostal theology does not operate as other theologies that often only detail a list of beliefs; it does this but also and (more) importantly, it explores them in the context of praxis. The Mystery of the Eucharist and its significance as a symbol for resistance is best reflected in the blessing of the Eucharist outside of the physical absence of minister - something that arguably symbolises his mystic presence in Communion, just as Christ is the mystic host and its openness to all people present, members and non-members.

Secondly, allowing non-baptised members to take part in the Communion fits well within Congar's understanding that the world can become 'sacred' in the sense that all of God's creation can be seen as signs of God's presence - not an ontological transformation but perceptual transformation on the part of the believers. In other words, faith and guidance of the Holy Spirit enable the Church to take up these worldly realities (pedagogically) and present them in such a way as to lead the world to the grace of Christ, including unbelievers and all of God's creation. To live sacramentally is to experience God's grace and to experience transformation, embrace diversity and bridge the divisions within the Church and society. In line with what Congar observed, in Mathew 26:26-28 when the Lord's Supper was constituted by Jesus on the night in which he was betrayed, these Scriptures show that there was no discrimination against anyone who should not sit on the table nor is there any mention of who should dispense the sacrament. However, although there is no reference to priests, we can observe in James 5:14-16 that elders could perform certain sacramental roles:

... Is any sick among you? Let him call for the elders of the church; and let them pray over him, anointing him with oil in the name of the Lord: 15 And the prayer of faith shall save the sick, and the Lord shall raise him up ...

\section{Eucharist as mundus inversus}

It is important to reiterate that the interface between the digital and religious spaces and practices that were generated and reflected through creatively engaged narratives in the context of the COVID-19 pandemic demonstrate how these intersections of new meanings are able to both modify traditional practices and create new meanings that arise from this creative engagement (Mpofu 2021):

\footnotetext{
... Although these phenomena are not new, but different given that religion and the printing press (technology) have always been linked, I consider this to be sacred transversality as it offers possibilities for new meanings generated by intersections between the religious (sacred) and digital (technological) spaces in the emerging context of virtual worship. (p. 4)
} 
Comparing these liturgical practices in the light of modern technology challenges the traditional understanding of 'sacred space' and helps us to re-appropriate the role of a priest as an embodiment of the presence of Christ, towards extending his physical presence to that of audio-visual presence and this is transformative mission. Given this transformative nature of God's sacrament of Holy Communion, it has a uniquely power-levelling function within the church and society where there are structural, social and economic divisions or injustices that place the powerful above the poor and marginalised. Sharing of the Eucharist through a televised blessing of bread and wine (as mundus inversus - the world upside down) disrupts the traditional understanding of liturgy and becomes transformative symbol of resistance in marginalised migrant communities who often have a desire to stay connected with their ministers from home countries. This community resembles what Laura Grillo (in Adogame \& Spikard 2010) has observed as the 'African Diaspora conceived as an epistemological community, a shared consciousness activating a sense of transnational affiliation across political boundaries'. In Psalm 113, we get the praises of God as the incomparable deity who inverts the situation of those condemned to a life of suffering and transforms hopeless circumstances in a life affirming manner. The Eucharist in this case becomes a transforming and empowering tool that can be used for agency and resistance by migrants and refugees who live on the borders and margins of society.

For example, in November 2003, Christians in Mexico joined hands with the Americans at US or Mexican border as the two communities on both sides of the iron fence came together in El Paso, Texas, to celebrate the Eucharist through liturgy designed to remember all saints and thousands of Mexican immigrants who died crossing the border from Mexico to the United States. They stood and worshiped together in two groups separated by the iron border fence, in defiance to the borders that divide and separate people. Standing in solidarity with each other, breaking bread and sharing wine across borders, they gave expression to their (Groody 2006):

[C]ommon solidarity as people of God beyond political constructions, the two communities joined alters on both sides of the wall. Even while border patrol agents and helicopters surrounded the liturgy and kept a strict vigilance, lest any Mexican cross over, people sang, worshiped and prayed. (p. 389)

Here, the bread and wine not only represented the body and blood of Jesus Christ (broken and shed for all) but also became a symbol of unity across borders and brought together a divided people in the presence of their resurrected Lord. The 'border patrol agents and helicopters' that surrounded liturgical space resembled Congar's (1967) understanding that the world - security and political authorities represented in this gathering - all became 'sacred' and were embedded into the sacred reality of the body of Christ's presence in the sense that all of God's creation can be seen as signs of God's presence. Therefore, it is possible that in future we could embrace witness the use of robots in performing some of the priestly roles performed by the clergy as part of reliance on technology to do God's mission.

\section{Conclusion}

This article compared how two congregations - one from Pentecostal and another from the reformed tradition conduct the Holy Communion services and recommended a re-thinking of the traditional approach to Christian traditions and the use of technology in the face of COVID-19 pandemic. The article also highlighted some positive aspects of COVID-19 disruptions on traditional practices with regard to observing sacraments and demonstrated how ontological questions help us discern what separates the sacred from the secular. By exploring the Pentecostal practices of disbursing the Holy Communion through a televised blessing in South Africa, the article reflects on the Reformed practice of celebrating the Eucharist and employs Yves Congar's concept of 'sacred pedagogy' to highlight the functional-ontological distinction between the world (including its own autonomously created technologies) and the 'sacred' body of Christ - as a lens to argue that understood 'pedagogically' and explored ethically - the mission of the Church should be understood as an extension of the incarnation of Christ to all of God's creation through modern technology. This paper challenged the traditional understanding of 'sacred space' and helps us to re-appropriate the role of a priest as an embodiment of the presence of Christ, towards extending his physical presence to that of audio or tele-visual presence - as an extension of the mission of God. Given the transformative nature of God's sacrament of the Holy Communion, paper also posited that COVID-19 disruptions are a uniquely power-levelling opportunity, which should be explored to re-appropriate the church's sacramental function in society where there are structural, social and economic injustices that place the powerful above the marginalised poor.

\section{Acknowledgements}

The author is indebted for the time he spent visiting the Lighthouse International Church in Pietermaritzburg.

\section{Competing interests}

The author declares that they have no financial or personal relationships that may have inappropriately influenced them in writing this article.

\section{Author's contributions}

B.M. is the sole author of this research article.

\section{Ethical considerations}

This article followed all ethical standards for research without direct contact with human or animal subjects. 


\section{Funding information}

The research received no specific grant from any funding agency in the public, commercial or not-for-profit sectors.

\section{Data availability}

Data sharing is not applicable to this article as no new data were created or analysed in this article.

\section{Disclaimer}

The views and opinions expressed in this article are those of the author and do not necessarily reflect the official policy or position of any affiliated agency of the author.

\section{References}

Adogame, A. \& Spikard, J., 2010, Religion crossing boundaries: Transnational religious and social dynamics in Africa and the new African diaspora, Brill, Leiden.

Arnold, A., 2018, 'How to (not) make the world sacred: Congar's sacred pedagogy', Provincial Council of the English Province of the Order of Preachers, London.

Christian Reformed Church, 2011, The Heidelberg Catechism, p. 91, viewed 06 May 2021, from https://www.crcna.org/sites/default/files/HeidelbergCatechism.pdf.

Congar, Y., 1967, Vatican II: La Liturgie après Vatican II - Unam Sanctam, p. 66, Editions du Cerf, Paris.

De Gruchy, J., 2013, “'Real presence” and sacramental praxis- reformed reflections on the Eucharist', NGTT 54(Suppl 5). https://doi.org/10.5952/54-0-348

Denny, L. \& Wepener, C., 2013, 'The spirit and the meal as a model for charismatic worship: A practical-theological exploration', HTS Teologiese Studies/Theological Studies 69(1), a2025. https://doi.org/10.4102/hts.v69i1.2025

Duce, J.L., 2013, 'A theological inquiry regarding the practice of the Eucharist in cyberspace', PhD thesis, University of Denver.

Groody, G.D., 2006, 'Fruit of the vine, work of human hands: Immigration and the Eucharist', Worship 80(5), 386-402.

Harris, M., 2017, 'God is a bot, and Anthony Levandowski is his messenger', Wired, September 27, 2017, viewed 22 June 2021, from https://www.wired.com/story/ god-is-a-bot-and-anthony-levandowski-is-his-messenger/.
Heyward, D., 2016, 'Watch the consecration ceremony, live from the Anagkazo Campus, Mampong - Ghana', YouTube, viewed 17 May 2021, from https://www. youtube.com/watch?v=dx3DmW5dEvk\&list=RDCMUCmpJUHS4ONNiHGCV_ youtube.com $/$ watch? $\mathrm{v}=\mathrm{d} \times 3 \mathrm{D}$.
K7ya-A\&start_radio $=1 \& \mathrm{t}=6442$.

Huyser-Honig, J., 2007, Lord's Supper practice in the reformed and Presbyterian tradition, viewed 22 March 2020, from https://worship.calvin.edu/resources/resource-library/ vowd-s-supper-practice-in-the-reformed-and-presbyterian-tradition/.
lord

Mbamalu, W., 2015, 'Worship and the Lord's Supper in assemblies of God, and other selected Pentecostal churches in Nigeria', HTS Teologiese Studies/Theological Studies 71(3), a2890. https://doi.org/10.4102/hts.v71i3.2890

McCain, D., 2011, “"Us and them": Pentecostal and other challenges and learning from each other', paper presented at the theological education in Africa conference, Theological College of Northern Nigeria (TCNN), s.n., s.l.

Mpofu, B., 2020a, 'Mission on the margins: A proposal for an alternative missional paradigm in the wake of COVID-19', HTS Teologiese Studies/Theological Studies 76(3), a6149. https://doi.org/10.4102/hts.v76i3.6149

Mpofu, B., 2020b, 'Navigating changing cultural landscapes: A quest for identity and belonging among migrant children and youth in Pietermaritzburg, South Africa', in Alternation Special Edition 34. Pietermaritzburg.

Mpofu, B., 2021, 'Transversal modes of being a missional church in the digital context of coronavirus disease 2019', HTS Teologiese Studies/Theological Studies 77(4), a6341. https://doi.org/10.4102/hts.v77i4.6341

Okyere Manu, B., 2018, 'Old wine in new Wineskins? Ethical reflections on liturgical practices and rituals in cyberspace', in Siwila \& R. Hewwit (eds.), Liturgy and identity, pp. 165-181, Cluster Publications.

Pillay, N., 2019, Artificial intelligence for Africa: An opportunity for growth development, and democratization, University of Pretoria, viewed 11 April 2020, from https://www.up.ac.za/media/shared/7/ZP Files/ai-for-africa. zp165664.pdf

Schuurman, D.C., 2019, 'Artificial intelligence: Discerning a Christian response', Perspectives on Science and Christian Faith 71(2), 75-82, viewed 22 June 2021, from https://www.asa3.org/ASA/PSCF/2019/PSCF6-19Schuurman.pdf.

Solon, O., 2017, 'Deus ex machina: Former Google engineer is developing an Al god', The Guardian, September 28, 2017, viewed 22 June 2021 from https://www. theguardian.com/technology/2017/sep/28/artificial-intelligence-god-anthonylevandowski.

Uniting Presbyterian Church (UPCSA), 1986, General directions for celebrating Holy Communion, service book and ordinal, UPCSA, p. 112.05E, Lovedale.

Watkins, K., 2011, The Eucharist and the church's story, viewed 06 May 2021, from http://www.bobcornwall.com/2011/07/eucharist-and-churchs-story-keith. html.

Weizenbaum, J., 1976, 'Computer power and human reason: From judgment to calculation', in W.H. Freeman (ed.), Artificial intelligence: Discerning a Christian
response: Perspectives on science and Christian faith, pp. 5-6, viewed 06 May 2021, from https://www.csca.ca/uploads/18Jan20SchuurmanDiscerningAl.pdf.

Wright, C.J.H., 2010, The mission of God's people, Zondervan, Grand Rapids, MI. 